\title{
ANALISIS SEKTOR BASIS DAN NON BASIS PADA PERTUMBUHAN EKONOMI DI KABUPATEN MADIUN TAHUN 2013-3017
}

\author{
Aldy Eko Wicaksono \\ Mahasiswa FEBI UINSA Surabaya \\ aldyeko@gmail.com
}

Penelitian ini menggunakan pendekatan deskriptif kuantitatif. Data yang digunakan merupakan data sekunder berasal dari data PDRB Provinsi dan Kabupaten. Metode yang digunakan dalam menentukan sektor unggulan di Kabupaten Madiun adalah Location Quotient (LQ), analisis Shift Share untuk mengidentifikasi tingkat pertumbuhan ekonomi.

Hasil dari analisis Location Qoutient (LQ) rata-rata pada tahun 2013207 dapat diketahui bahwa yang tergolong sektor basis di Kabupaten Madiun adalah (I) Sektor Pertanian, Kehutanan dan Perikanan, (2) Sektor Pengdaan air, Pengelolaan Sampah, Limbah dan Daur Ulang, (3) Sektor Konstruksi, (4) Sektor Informasi dan Komunikasi, (5) Sektor jasa Keuangan dan Asuransi, (6) Sektor Real Estat, (7) Sektor Administrasi Pemerintahan, Pertahanan dan Jaminan Sosial Wajib, (8) Sektor Jasa Pendidikan, (9) Sektor Jasa Kesehatan dan Kegiatan Sosial, (10) Sektor lainnya. Memiliki nilai Location Quotient (LQ) lebih dari satu (LQ>I), dengan demikian dapat diartikan bahwa sektor ekonomi tersebut mampu mengekspor hasil produksinya ke daerah lain. Hasil dari analisis Shift Share (SS) sektor basis yang memiliki daya saing yaitu I) Pertanian, Kehutanan dan Perikanan, (2) Pengadaan Air, Pengelolaan Sampah, Limbah dan Daur Ulang, (3) Kontruksi, (4). Informasi Komunikasi (5). Jasa Keuangan dan Asuransi, (6) Real Estate (7) Administrasi Pemerintahan, Pertahanan dan Jaminan Sosial Wajib (8) Jasa Pendidikan (9) Jasa Kesehatan dan Kegiatan Sosial (10) Jasa Lainnya. Sektor tersebut mempunyai peran yang besar terhadap PDRB. Sektor tersebut sangat berarti bagi Pertumbuhan ekonomi Kabupaten Madiun.

Peneliti menyarankan pemerintah Kabupaten Madiun untuk memprioritaskan pengembangan sektor yang menjadi basis serta memiliki bertumbuhan dan daya saing yang tinggi guna untuk meningkatkan perekonomian pada Kabupaten Madiun.

Keyword : Sektor Basis, LQ, Shift Share 


\section{Pendahuluan}

Tujuan utama dari usaha-usaha pembangunan ekonomi selain menciptakan pertumbuhan ekonomi yang setinggi-tingginya, harus pula manghapus atau mengurangi tingkat kemiskinan, ketimpangan pendapatan dan tingkat pengangguran. Kesempatan kerja bagi penduduk atau masyarakat akan memberikan pendapatan untuk memenuhi kebutuhan hidupnya. Ketersediaan lapangan kerja yang luas akan mampu mendorong tingkat pertumbuhan ekonomi karena akan dapat mendorong ekonomi dari segi pendapatan masyarakat.

Realitas peningkatan PDRB, misalnya tidak serta merta disimpulkan sebagai kenaikan kesejahteraan bagi seluruh masyarakatnya. Jika kenaikan PDRB tersebut hanya disumbangkan oleh sektor tertentu, katakanlah sektor industri/manufaktur (padahal yang bekerja di sektor itu tidak banyak), maka peningkatan PDRB itu hanya terkonsentrasi pada penduduk tertentu sehingga menimbulkan disparitas pendapatan. Oleh karena itu, sumbangan sektoral terhadap PDRB juga perlu dipertimbangkan untuk menganalisis kondisi ekonomi daerah. Selain pada jangka menengah pertumbuhan ekonomi diharapkan dapat mengurangi pengangguran melalui peningkatan kesempatan kerja pada sektor-sektor yang memiliki kontribusi tinggi baik secara langsung maupun tidak langsung.

Perkembangan perekonomian serta prosesnya yang berkesinambungan adalah sebuah keadaan yang penting untuk keberlangsungan pengembangan perekonomian di suatu wilayah. Bertambahnya jumlah penduduk yang semakin meningkat di tiap tahunnya diyakini bahwa keperluan setiap individu juga akan meningkat. Maka diperlukannya ekstra penghasilan pada setiap bulannya. Penghasilan ekstra tersebut bssa didapatkan melalui cara meningkatkan jumlah produksinya alias Produk Domestik Regional Bruto (PDRB). ${ }^{1}$

\footnotetext{
' Ahmad Usman Ali \& Abu Bakar,Analisis Sektor Unggulan Dalam Struktur Perekonomian Kabupaten Mimika,Jurnal Ekonomi, 2016
} 


\section{Landasan Teori}

1. Konsep Pertumbuhan Ekonomi Wilayah

Pertumbuhan ekonomi wilayah adalah sumber utama pada pengembangan di suatu daerah. Oleh sebab itu pertumbuhan daerah adalah suatu hal yang sangat penting untuk melakukan pengembangan di suatu daerah atau wilayah, bisa juga disebutkan pertumbuhan ekonomi wilayah ini adalah sebuah fundamental dari pembangunan wilayah itu sendiri. Tujuan utama dari suatu konsep atau teori pertumbuhan wilayah sendiri adalah untuk mengetahui kenapa bisa terjadi suatu daerah atau wilayah mengalami pertumbuhan perekonomian yang pesat dan mengapa pula suatu daerah atau wilayah pertumbuhan perekonomiannya melemah. Konsep dan teori ini juga memiliki sebuah fokus yaitu untuk meningkatkan pertumbuhan perekonomian di suatu daerah atau wilayah saja tidak untuk nasional. Namun jika perekonomian disuatu daerah berkembang maka pertumbuhan perekonomian nasional juga ikut berkembang. ${ }^{2}$

Menurut Boediono pertumbuhan ekonomi ialah sebuah cara untuk menaikkan hasil produksi per kapita pada jangka waktu ynag panjang, jika ingin proses pertumbuhan ekonomi itu terjadi presentase pertambahan hasil produksi haruslah lebih tinggi dari pada yang bertambahnya jumlah penduduk serta adanya indikator pada jaringan untuk pertumbuhan yang berkelanjutan.

Pada usaha untuk mengembangkan pertumbuhan perekonomian pada suatu daerah, dibutuhkan sebuah skill untuk menjelaskan apa saja keunggulan perekonomian di suatu wilayah, salah satunya adalah menetapkan apa saja sektor- sektor yang memiliki potensi untuk dikembangkan yang bertujuan agar perekonomian disuatu wilayah akan

2 M.L Jhingan, “Ekonomi Pembangunan dan Perencanaan”, (PT. Raja Grafindo, Jakarta, 2016), Hal. 6 
bertumbuh secara pesat serta di lain sisi dapat menjelaskan indikator yang membuat sektor tertentu berkembang secara lambat serta melakukan tindakan preventif kenapa sektor tersebut berkembang secara lambat. ${ }^{3}$

2. Konsep Pembangunan Ekonomi Wilayah

Pembangunan ekonomi merupakan sebuah aktivitas yang pasti dilaksanakan pada tiap wilayah yang bertujuan untuk membanguan perekonomian di wilayah tersebut dan untuk meningkatkan kesejahteraan penduduknya. Pengertian lainnya pada pembangunan ekonomi ialah sebuah kegiatan yang menyebabkan timbulnya pendapatan masyarakat disuatu wilayah meningkat dalam periode waktu yang panjang, menurut Sadono Sukirno terdapat 3 (tiga) sifat penting dalam pembangunan ekonomi yaitu (1) Pembangunan ekonomi sebagai suatu proses, (2) Usaha meningkatkan Pendapatan Perkapita, (3) Kenaikan Pendapatan perkapita harus berlangsung jangka panjang. ${ }^{4}$

Schumpter menyatakan bahwa pembangunan ekonomi adalah kenaikan output yang disebabkan oleh inovasi yang dilakukan oleh para wiraswasta. Inovasi ini berarti perbaikan teknologi dalam arti luas, misalnya penemian produk baru, pembukaan pasar baru dan sebagainya. Sedangkan pembangunan ekonomi untuk daerah, makna yang tradisional difokuskan pada peningkatan PDRB suatu Provinsi, kabupaten atau kota. ${ }^{5}$

3. Konsep Basis Ekonomi

Konsep dari basis ekonomi ini sendiri pertama kali diperkenalkan oleh Douglas C.North pada tahun 1956, menurut Douglas konsep basis ekonomi ini bergantung pada suatu wilayah dan konsep ini dipastikan pada

${ }^{3}$ Robinson Tarigan, "Ekonomi Regional Teori dan Aplikasi”, (Jakarta: Bumi Aksara, 2005), Hal.47

${ }^{4}$ Sadono Sukirno, Ekonomi Pembangunan, (Bima Grafika, Jakarta, 1985), Hal I3.

5 Jhingan, “Ekonomi Pembangunan dan Perencanaan”, (Jakarta, PT Raja Grafindo, 2016), Hal. 4. 
banyaknya keunggulan kompetitif yang dipunyai oleh daerah tertentu. Jika pada daerah tertentu tersebut memiliki sejumlah sektor- sektor yang dapat bersaing dengan sektor lain di luar daerah tersebut sehingga memungkinkan melakukan ekspor ke daerah lain, maka sudah dipastikan peningkatan ekspor menghasilkan efek yang besar dan menguntungkan bagi ekonomi di daerah tersebut. ${ }^{6}$

Pada teori basis ini sendiri dibagi menjadi 2 bagian, yaitu sektor basis dan sektor non basis. Sektor basis merupakan sektor yang dapat memenuhi kebutuhan pada wilayahnya atau regionalnya sendiri sehingga wilayah tersebut dapat melakukan kegiatan ekspor barang atau jasa keluar regional atau wilayah itu. Sedangkan sektor non basis merupakan sektor yang belum mampu untuk memenuhi keinginan pasar di wilayahnya tersebut sehingga sektor non basis ini tidak dapat melakukan ekspor barang maupun jasa kepada regional atau wilayahnya. ${ }^{7}$

Cara untuk menentukan sebuah sektor dikatakan basis atau non basis dapat ditentukan dengan metode analisis Location Quotient (LQ). Analisis LQ ini dipergunakan untuk menentukan apakah sektor tersebut dapat dikatakan basis atau non basis dengan membandinggkan kontribusi sektor tersebut pada perekonomian daerah. LQ sendiri memanfaatkan nilai Produk Domestik Regional Bruto (PDRB) di kabupaten/kota tertentu lalu melakukan perbandingan dengan nilai PDRB wilayah Provinsi/Nasional. ${ }^{25}$ Jika nilai dari perhitungan Location Quotient (LQ) pada suatu sektor $\geq 1$ maka sektor tersebut dapat dikatakan sebagai sektor basis atau sektor unggulan perekonomian di wilayah tersebut, tetapi apabila perhitungan LQ pada suatu sektor $\leq 1$ maka sektor tersebut dapat dikatakan

${ }^{6}$ Sjafrizal, Ekonomi Wilayah dan Perkotaan, (Raja Grafindo Persada: Padang, 20I2), halaman 90.

7 Darmian, "Analisis Sektor Unggulan dan Penyerapan Tenaga Kerja di Provinsi SulwesiTenggara" (Skripsi Universitas Haluoleo, 2016), hal. 8. 
Analisis Sektor Basis Dan Non Basis Pada Pertumbuhan Ekonomi

Di Kabupaten Madiun Tahun 2013-2017

sektor non basis atau bukan sektor unggulan perekonomian di wilayah tersebut. ${ }^{8}$

\section{Jenis Penelitian}

1. Kerangka Penelitian

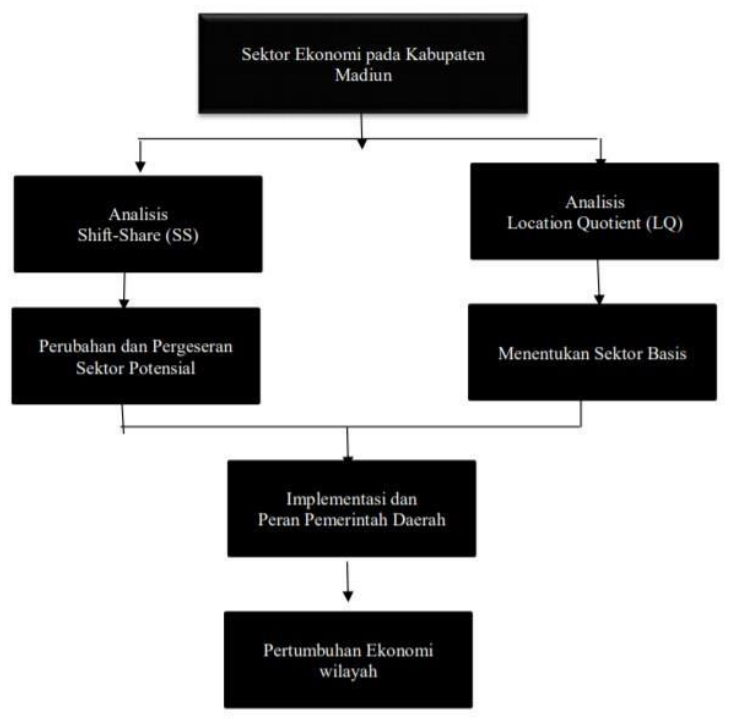

${ }^{8}$ Darmian, "Analisis Sektor Unggulan dan Penyerapan Tenaga Kerja di Provinsi Sulawesi Tenggara" (Skripsi Universitas Haluoleo, 2016), hal. 9. 


\section{Jenis Penelitian}

Pada penelitian kali ini, penulis akan meneliti tentang analisis sektor basis dan non basis terhadap pertumbuhan ekonomi pada Kabupaten Madiun. Penulis akan mecari data dari lembaga atau instansi yang berhubungan pada penelitian ini, setelah memperoleh data penulis akan menggunakan metode serta analisis yang bertujuan untuk menggali informasi yang ada. Penelitian ini dibuat menggunakan pendekatan deskriptif kuantitatif, pendekatan ini betujuan untuk memperlihatkan keseluruhan objek penelitian yang akan di teliti. Dan dapat di tegaskan kesimpulan yang ada pada penelitian ini dapat di pertanggung jawabkan, sehingga dapat diketahui analisis sektor basis non basis terhadap pertumbuhan ekonomi pada Kabupaten Madiun tahun 2013-2017.

Penelitian ini sendiri akan bertujuan untuk melihat analisis sektor basis dan non basis terhadap pertumbuhan ekonomi pada Kabupaten Madiun. Arti dari waktu penelitian ini sendiri adalah jangka waktu yang akan di pergunakan oleh peneliti untuk melakukan penelitian ini kurang lebih pada bulan Oktober 2018 di Provinsi Jawa Timur. Sesuai judul maka penelitian ini mengambill 4 tahun yaitu tahun 2013- 2017.

Pada penelitian ini menggunakan sempel berupa laporan Produk Domestik Regional Bruto (PDRB) Provinsi Jawa Timur, Laporan PDRB Kabupaten Madiun pada tahun 2013-2017.

\section{Variabel Penelitian}

Penelitian ini memakai pendekatan kuantitatif yang mana metode ini menggunakan kalkulasi dalam angka. Terdapat 2 (dua) variabel pada penelitian ini yang pertama variabel $X$ adalah Sektor Basis dan Non Basis dan yang kedua ada variabel $\mathrm{Y}$ adalah Pertumbuhan Ekonomi. Kemudian penelitian ini sendiri berlokasi di Provinsi Jawa Timur lebih tepatnya pada kota Surabaya dan Kabupaten Madiun. Sehingga 2 (dua) variabel akan menjelaskan tentang Analisis 
Sektor basis dan Non Basis Terhadap Pertumbuhan Ekonomi pada Kabupaten Madiun Tahun 2013-2017.

4. Metode Pengumpulan Data

Pada Penelitian ini teknik pengumpulan data menggunakan metode dokumentasi. Metode ini adalah metode pengumpulan data yang diperoleh dari instansi terkait yang relevan dengan penelitian yang sedang di teliti.

\section{Analisa Data}

1. Metode Analisis Data

1) Metode Location Quotient

Metode analisis Location Quotient (LQ) bertujuan untuk menentukan sektor unggulan di suatu wilayah. Dengan adanya metode ini suatu wilayah dapat mengetahui sektor mana saja yang merupakan sektor unggulan (sektor basis), dimana analisis ini menggunakan data Produk Domestik Regional Bruto (PDRB) sehingga memiliki rumus sebagai berikut:

\section{Dimana:}

$$
\mathrm{LQ}=(\mathrm{yi} / \mathrm{yt}) /(\mathrm{Yi} / \mathrm{Yt})
$$

yi $=$ Pendapatan sektor ekonomi di Kabupaten Madiun.

yt = Pendapatan total Kabupaten Madiun (PDRB).

Yi $=$ Pendapatan sektor ekonomi di Provinsi Jawa Timur.

$\mathrm{Yt}=$ Pendapatan total ekonomi Provinsi Jawa Timur. ${ }^{9}$

\section{2) Metode Analisis Shift-Share}

Metode analisis Shift-Share adalah sebuah metode dalam menganalisa sebuah perubahan perkonomian disuatu daerah yang membandingkan dengan perekonomian provinsi atau nasional. Analisis Shift-Share ini bertujuan untuk menetapkan tingkat produktivitas perekonomian yang berada di wilayah dengan wilayah yang lebih luas. Berikut rumus analisis ShiftShare:

$$
\mathrm{Dij}=\mathrm{Nij}+\mathrm{Mij}+\mathrm{Cij}
$$

\footnotetext{
${ }^{9}$ Suhardi, "Analisis Shift Share dan Location Quotients Dalam Penentuan Sektor Basis di Kabupaten Aceh Timur Tahun 2003-2007", (Skripsi-Universitas Muhammadiyah Surakarta, Surakarta, 2008), Hal I4
} 
Dimana:

Dij $=$ Perubahan sektor $\mathrm{i}$ di daeah $\mathbf{j}$.

$\mathrm{Nij}=$ Pertumbuhan nasional sektor $\mathrm{i}$ di daerah $\mathrm{j}$.

Mij = Bauran industri sektor $\mathrm{i}$ di daerah $\mathrm{j}$.

Cij $=$ Keunggulan kompetitif sektor i di daerah j.10

2. Pembahasan

Pada Kabupaten Madiun perkembangan Produk Domestik Regional Bruto (PDRB) setiap tahun meningkat hall ini di akibatkan oleh adanya peralihan pada jumlah barang dan jasa pembuatan barangg dan jasa yang dihasiilkan pada perubahan harga, cara agar mengetahui seberapa tingkat perubahan tersebut ada faktor pengarruh harga yang dihilangkan,yaitu dengan mengkalkulasi PDRB Atas Harga Konstan (ADHK).

PDRB Atas Dasar Harga Konstan (ADHK) dari tahun 2012 hingga tahun 2016 mengalami kenaikan, lalu pada PDRB Atas Dasar Harga Berlaku (ADHK) mengalami peningkatan dari tahun 2012 hingga tahun 2016. Tetapi pada presentasi pertumbuhan ekonomi pada Kabupaten Madiun dari tahun 2012 hingga tahun 2016 mengalami penurunan tetapi hanya beberpa persen saja.

Sektor basis yang terdapat pada Kabupaten Madiun yaitu (1) sektor pertanian, kehutanan, dan perikanan dengan nilai $L Q$ sebesar 2,61 (2) sektor pengadaan air, pengelolaan sampah, limbah dan daur ulang dengan nilai $L Q$ sebesar 1,74 (3) sektor konstruksi dengan nilai $L Q$ sebesar 1,22 (4) sektor informasi dan komunikasi dengan nilai $L Q$ sebesar 1,39 (5) sektor jasa keuangan dan asuransi dengan nilai $L Q$ sebesar 1,08 (6) sektor real estate dengan nilai $L Q$ sebesar $1,03 \quad(7)$ sektor administrasi pemerintahan, pertahanan, dan jaminan sosial wajib dengan nilai $L Q$ sebesar 2,57 (8) sektor jasa pendidikan dengan nilai $L Q$ sebesar 1,66 (9) sektor jasa kesehatan dan kegiatan sosial dengan nilai $L Q$ sebesar 1,34 (10) sektor jasa lainnya dengan nilai $L Q$ sebesar 1,72 .

${ }^{10}$ Rahardjp Adisasmita, Pertumbuhan Wilayah dan Wilayah Pertumbuhan, (Graha Ilmu: Yogyakarta, 2014) hal. 91. 
Sedangkan sektor non basis pada perhitungan diatas adalah (1) Sektor Pertambangan dan Penggalian, (2) Sektor Industri Pengolahan, (3) Sektor Pengadaan Listrik dan Gas, (4) Sektor Perdagangan Besar dan Eceran; Reparasi Mobil dan Sepeda Motor, (5) Sektor Transportasi dan Pergudangan, (6) Sektor Penyediaan Akomodasi dan Makan Minum, (7) Sektor Jasa Perusahaan. Sektor ekonomi tersebut memiliki nilai LQ lebih kecil dari 1 (LQ<1), hal ini dapat disumpulkan bahwa sektor ini belum dapat mencukupi kebutuhan di regionalnya.

\section{Penutup}

Berdasarkan hasil perhitungan dari Analisis Loction Quotients (LQ) Terdapat sepuluh sektor Unggulan Kabupaten Madiun yang menjadi basia ekonomi daerah yaitu, Sektor Pertanian, Kehutanan dan Perikanan, Sektor Pengadaan Air, Pengelolaan Sampah dan Limbah Daur Ulang. Sektor Konstruksi, Sektor Informasi dan Komunikasi, Sektor Jasa Keuangan dan Asuransi, Sektor Real Estate, Sektor Administrasi Pemerintahan dan Jaminan Sosial Wajib, Sektor Jasa Pendidikan, Sektor Jasa Kesehatan dan kegiatan Sosial. Sedangkan ada tujuh sektor yang merupakan sektor non ungguan yaitu, Sektor Pertambangan dan Penggalian, Sektor Industri Pengolahan, Sektor Pengadaan Listrik dan Gas.Sektor Perdagangan Besar dan Eceran; Reparasi Mobil dan Sepeda Motor, Sektor Transportasi dan Pergudangan, Sektor Penyediaan Akomodasi dan Makan Minum, Sektor Jasa Perusahaan 


\section{DAFTAR PUSTAKA}

Adisasmita, R. (2014). Pertumbuhan Wilayah dan Wilayah Pertumbuhan.Yogyakarta: Graha Ilmu.

Ali, A. U., \& Bakar, A. (2016). Analisis Sektor Unggulan Dalam Struktur Perekonomian Kabupaten Mimika. Jurnal Ekonomi .

Amalia, F. (2012). Penentuan Sektor Unggulan Perekonomian Wilayah Kabupaten Bone Bolango dengan Pendekatan Sektor Pembentuk PDRB. Jurnal Ekonomi , XI (2).

Arsyad, L. (2002). Pengantar Perencanaan dan Pembangunan Ekonomi Daerah. Yogyakarta: BPFE.

Basuki, A. T., \& Gayatri, U. (2004). Penentu Sektor Unggulan Dalam Pembangunan Daerah Studi Kasus di Kabupaten Ogan Komering Ilir. Jurnal Ekonomi dan Studi Pembangunan, $X(1)$.

Basuki, M., \& Mujiharjo, F. N. (2017). Analisis Sektor Unggulan Kabupaten Sleman dengan Metode Sift Share dan Location Qoutient. Jurnal Sains Teknologi dan Industri, 15 (1).

BPS Kabupaten Madiun. (2018). Diambil kembali dari BPS Kabupaten Madiun:https://madiunkab.bps.go.id/

Cikitha, P., Anna, Z., Suryana, A. H., \& Nurhayati, A. (2018). Analisis Peran Sektor Perikanan Terhadap Pembangunan Wilayah Kabupaten Kuningan Jawa Barat. Jurnal Perikanan dan Kelautan, IX (1).

Darmian. (2016). Analisis sektor Unggulan dan Penyerapan Tenaga Kerja di Provinsi Sulawesi Tenggara (Skripsi). Universitas Haluoleo. Universitas Haluoleo.

Diana, M., Sulistiowati, D., \& Hadi, S. (2017). Analisis Sektor

Ekonomi Unggulan Provinsi Maluku Utara. Jurnal Ilmu Ekonomi, I. Harinta, Y. W., Basuki, J. S., \& Sukaryani, S. (2018). Pemetaan dan

Pengembangan Agribisnis Komoditas Unggulan Sayuran di Kabupaten Karanganyar. Jurnal Agriekonomika, VII (1). 
Husna, N., Noor, I., \& Rozikin, M. (2016). Analisis Pengembangan Potensi Ekonomi Lokal untuk Menguatkan Daya Saing Daerah di Kabupaten Gresik. Jurnal Administrasi Publik, I (1).

Ibrahim, I. (2018). Analisis Potensi Sektor Ekonomi dalam Upaya Peningkatan Pertumbuhan Ekonomi. Jurnal Ekonomi , I (1-2).

Jhingan, M. L. (2016). Ekonomi Pembangunan dan Perencanaan. Jakarta: PT. Raja Grafindo.

Latuny, E. (2014). Analisis Sektor Ungglan di Provinsi Maluku (Skripsi). Universitas Pattimura, Fakultas Ekonomi.

Ma'aruf, A., \& Wihastuti, L. (2008). Pertumbuhan Ekonomi Indonesia: Determinan dan Prospeknya. Jurnal Ekonomi dan Studi Pembangunan, IX (1).

Nur, I., Mulatsih, S., \& Asrama, A. (2013). Analisis Struktur Perekonomian dan Faktor-Faktor yang Memengaruhi Pertumbuhan Ekonomi Sumatera Selatan. Jurnal Ekonomi dan Kebijakan Pembangunan, II (1), 47-59.

Nursalam. (2012). Statistik untuk Penelitian Teknik Sampling (Edisi Pertama ed.). Makassar: Makassar Alauddin University Press.

Putra, A. N. (2013). Analisis Potensi Ekonomi Kabupaten dan Kota di Provinsi Daerah Istimewa Yogyakarta (Skripsi). Jakarta: Universitas Islam Negeri Syarif Hidayatullah Jakarta.

Safwandi, I., \& Rangkuti, M. S. (2018). Analisis Struktur Ekonomi dan Sektor Unggulan Kabupaten Aceh Besar. Jurnal Humaniora, II (1).

Sholeh, A. (2012). Kontribusi dan Daya saing Ekspor Sektor Unggulan dalam Perekonomian Jawa Timur. 2012: Universitas Diponegoro.

Sjafrizal. (2012). Ekonomi Wilayah dan Perkotaan. Padang: Raja Grafindo Persada.

Sjafrizal. (2014). Perencanaan Pembangunan Daerah dalam Era Otonomi. Jakarta: Raja Grafindo Persada.

Suhardi. (2008). Analisis Shift Share dan Location Quotients dalam Penentuan Sektor Basis di Kabupaten Aceh Timur 20032007 (Skripsi). Surakarta: Universitas Muhammadiyah Surakarta. 
Sujarweni, W. (2015). Metodologi Penelitian Bisnis dan Ekonomi. Yogyakarta: Pustaka Baru Press.

Sukirno, S. (1985). Ekonomi Pembangunan. Jakarta: Bima Grafika.

Sumayow, A. G., Pangemanan, P. A., \& Tangkere, E. G. (2018).

Analisis Sektor Basis dan Non Basis di Kabupaten

Bolang Mongondow Timur. Jurnal Ekonomi

Susanto, A. (2008). Analisis Sektor Potensial dan Pengembangan Wilayah Guna Mendorong Pembangunan di Kabupaten Rembang. Jurnal Ekonomi dan Manajemen, IX No 2.

Tarigan, R. (2005). Ekonomi Regional Teori dan Aplikasi. Jakarta: Bumi Aksara.

Wijaya, D. (2012). Analisis Penentuan Sektor Unggulan Perekonomian Wilayah Kabupaten Ngawi (Skripsi).

Universitas Sebelas Maret. 